\title{
ON THE MOVE
}

The world has radically changed since this research concluded and tensions over borders, mobility, and people on the move are more extreme both globally and in Eurasia than they have been in decades. More than four million Syrians have been displaced by civil war since 2011, with more than three million registered as refugees in Turkey, and many also seeking to transit through Turkey in search of refuge in Europe. Escalating violence and government repression have defined the public sphere in Turkey, with a failed coup in July 2016 and a subsequent political purge of more than 130,000 people (Kingsley 2017). ${ }^{1}$ In late November 2016 Prime Minister Erdoğan threatened to open the "border gates" and permit the predominantly Syrian refugees residing in Turkey to access the EU, a move that reflects Erdoğan's confidence in Turkey's essential role in policing mobility for Europe at a time when the EU's future is tenuous. These events highlight how geopolitical balances of power have significant consequences for refugees and migrants. ${ }^{2}$

Whereas the end of the Soviet Union was marked by the easing of border restrictions and hypermobility in Eurasia, the current global order is defined by popular calls for securitization and border regulation. If in the two decades following the end of the Soviet Union labor migrants and well-heeled flexible citizens traversed relatively permeable borders, we are now in a different era, one of global anxiety. Under the leadership of President Vladimir Putin Russia has intensified policing of the relatively open borders that citizens of the former Soviet Union have crossed since 1991, and anti-migrant sentiment has become 
commonplace. ${ }^{3}$ The sentiment shared by many in this part of Eurasia is reflective of a global shift away from an era defined by globalization and a move toward isolationism. Since the end of the Soviet Union people have come to rely on their ability to engage in a myriad of border crossings for trade and circuits of labor migration, as well as to provide for households and pursue personal aspirations, but this era appears to be ending.

\section{Empires and Circuits}

Less than a decade following the end of the Soviet Union and the fall of the Berlin Wall Daphne Berdahl wrote, "Tensions between East and West, as well as the tension produced by each system's contrasting ideologies of gender and womanhood, continue to be assimilated and negotiated in multiple and diverse ways" (1999, 205). In Berdahl's formulation "East" and "West" referenced political formations of "capitalism" and "state socialism" and suggested a sharp divide between them. Such an "East"- "West" binary seems less salient now than it did two decades ago. As migrant women have spent time outside the borders of the former Soviet Union, become immersed in new forms of labor, and negotiated intimate practices at home and abroad, they have become similar to other marginalized women on the move globally (Colen 1995; Ehrenreich and Hochschild 2002). Moreover, as the memory of state socialism fades, it is likely to become just one of the many historical forces shaping the region, with the binary of capitalism and state socialism becoming less important.

Nevertheless, one must also carefully take into account local histories to identify the forms that power and disempowerment take. In the first decade of the new millennium, the meanings people attached to socialist and postsocialist frames of reference continued to have salience for them. The ways that migrants have imagined intimate ties across borders have been fundamentally shaped by generations of socialist ideology and social practice that were informed by ideals of gender equality, meaningful labor, and expectations of a state that would provide for the needs of its citizens. For the immediate future this frame continues to be critical for understanding the shifting gender systems, structures of feeling, and processes of mobility that define the region. When Kara, the entertainer from Ukraine who was saving money to help her brother pay for school and her mother migrate to Italy, rhetorically asked me, "How can a government stand by while its population is forced to flee abroad to make a living?" she was not asking this in the abstract. Kara was angrily reacting to the abrogation of a historically specific social contract. For Kara and others, the legacy of a socialist state continues to be substantial, with an expectation that states should provide for their citizens, so men and women would not have to pursue their aspirations beyond their homelands. 
The transnational flows discussed in these pages have multiple origins and destinations, with the primary flow I have traced moving between north and south, from Russia to Moldova to Turkey. Other flows are also part of the story, as when southern Moldovans like Bella, with ethnic ties to Romania or Bulgaria, are drawn into additional transnational circuits, and when thousands of Turkish male contract workers live long-term doing construction in Russia and Kazakhstan. Critically thinking about these transnational flows reorients unidirectional arrows suggested by models of modernization. Instead, attention can turn to the circuits where people, money, and imagery, such as that circulated by The Magnificent Century, move along conduits often forged by trade but also built on long histories of cultural and political connection. In all these flows, to some degree, people are pursuing aspirations for a newly radiant future inherently linked to the very act of mobility. In this way the post-Soviet story of labor migration into Turkey provides a portal onto how people fare as empires wax and wane.

\section{Intimacy}

In focusing my attention on intimacy in multiple forms, I have sought to trace both the "costs" of global capitalism for women and their households and the possibilities created by mobility. While intimate practices in multiple registersfor example, sexuality without hang-ups, strategic romance and marriage, and other mothering-were recognizable forms, I also hope to have humanized people by showing the diverse types of relationships women are managing and by enmeshing women within relationships with each other, as well as with lovers, families, and communities. The sudden ability to cross borders in the early 1990 s was a sort of revelation for many women. In conversation, women periodically reminded me that labor migration was not just about earning a living or suffering without one's family. In one memorable instance, one afternoon in Istanbul Zina recalled the 1990s as an exhilarating time to be employed in Turkey, and she confided, smiling slyly, "My dear, I did not always clean houses ... I had other work too." She went on to describe with relish how when she worked as a sales assistant she would travel regularly between Ukraine and Turkey, carrying up to $\$ 50,000$ strapped to her body for payment on goods that had been sent from Turkey to Ukraine. The routes south to Istanbul opened up possibilities for a sense of exhilaration, as well as for the prospect of providing for households back in home communities. These stories of a sense of expanding horizons, along with the ability to maintain intimate ties both locally in Istanbul and transnationally-through a nurturing nexus with children, parents, and other relatives back home-have proven to be a central element of these gendered transnational circuits. 


\section{States and the Future}

By virtue of being engaged in transnational circuits, moving between marginal hometowns and cosmopolitan centers like Istanbul, the women I came to know negotiated the barriers of multiple states and gained immeasurable expertise. Women became experts in import/export operations, with specialized knowledge of how much could be packed of what to cross which borders. They also became local immigration consultants with insider knowledge of what it takes to obtain visas and renew passports, what would be sure to create impediments at the border, and what alternative travel routes could be taken. And they often became savvy capitalists, whether or not they embraced this development. With the end of the Soviet Union, which women often told me emphatically was a "tragedy" (tragediia) for them and their families, people became a new type of neoliberal subject, seeking out opportunities and shouldering responsibility for services the state provided in the past. As Zina explained in Istanbul one afternoon, "We have had to learn how to play the system; we had to learn that no one will look out for us." More than anything else, in a short period of time the women I came to know had remade themselves to make a living, while continuing to dream of better lives.

In a Skype call with Bella as the final pages of this book were coming together, she reflected on what years of labor migration have meant for her. "I worked for more than ten years in Russia and nearly seven years in Istanbul, and what do I have to show for it? I did put my sons through postsecondary education in Romania; oi, that involved a lot of running around! But what is left?" At age fifty-two Bella had just returned to Moldova to live, and she reflected on her job search. She told me she had recently been turned down for a position in a call center where, as she described, "you would have to sell people things they don't want." She was back to hanging wallpaper in apartment renovations, work she had been doing when she first arrived in Moscow in 2003 but also work that did not provide for her pension or health insurance. She had gone off into a transnational migration circuit and returned, but she faced the same indifferent state that she had left behind when she departed in search of something better nearly twenty years earlier. In an era of transnational flows, including of migrants and refugees, in many places states have become even less accountable to their growing number of absent citizens, and destination states have felt little obligation to safeguard rights or well-being for non-citizens, people on the move.

As this generation of post-Soviet migrants ages, and many of the next generation also become labor migrants, what will the future bring as a global underclass continues to travel long distances to labor in the households and intimate service sectors of more wealthy, privileged global centers? Will the next 
generation-migrants' children-come up with a way to pressure their governments to address their plight as marginalized citizens in the world? Will international efforts coalesce around guaranteed basic rights for people on the move? It is possible that outrage like Eva's about southern Moldova being a "colony" of "slaves" laboring for global capitalism could bring about an effective solidarity movement among post-Soviet labor migrants. Even without such a movement, in recognizing the myriad ways that labor migrants manage to forge meaningful lives we can begin to appreciate their negotiations with shifting forms of power. The potent combination of transnational circuits, shifting ideals about gender and intimacy, and intimate bonds between Turkish men and Russian-speaking women is part of the unfolding story of how new configurations of global capital shape personal lives but also the story of how migrants make lives for themselves despite the injustices of this newly precarious world. 